\title{
Rare and rare-earth metals industry development in Russia and its influence on fourth world energy transition
}

\author{
O. V. Zhdaneev, PhD, Deputy CEO ${ }^{1}$, Leading Researcher ${ }^{2}$, Associate Professor ${ }^{3}$, e-mail: Zhdaneev@rosenergo.gov.ru \\ Ye. I. Petrov, Head of the Agency ${ }^{4}$, e-mail: rosnedra@rosnedra.gov.ru \\ A. A. Seregina, Candidate of Political Sciences, Associate Professor of the Department of World Economy ${ }^{5}$, Project \\ Director at the Directorate of Technologies in the Fuel and Energy Complex ${ }^{1}$, e-mail: a.seregina@dipacademy.ru, \\ ORCID: 0000-0002-2090-4061 \\ ${ }^{1}$ Federal State Budgetary Organization "Russian Energy Agency"( REA) by the Ministry of Energy of the Russian Federation, \\ Moscow, Russia. \\ ${ }^{2}$ A. V. Topchiev Institute of Petrochemical Synthesis of Russian Academy of Sciences, Moscow, Russia. \\ ${ }^{3}$ National University of Oil and Gas "Gubkin University", Moscow, Russia. \\ ${ }^{4}$ Federal Agency for Mineral Resources, Moscow, Russia. \\ ${ }^{5}$ The Diplomatic Academy of the Ministry of Foreign Affairs of the Russian Federation, Moscow, Russia.
}

\begin{abstract}
The typical life cycle of a Russian extractive project starting from the field is licensing all the way to the physical launch and commissioning of the plant is, on average, at least 10 years. Such a long construction cycle increases the discounted payback period by more than 15 years, at the desired rate of 8 years. Based on the principles of rational use and protection of subsoil, Russian legislation is advanced in terms of reliability, safety, sustainability. However, the current standards and regulations do not allow to move to the active phase of setting up enterprises for the extraction, processing of rare (RM) and rare-earth (REM) metals and to create an industry with a full production cycle in a shorter time frame. It should be noted that the basic technologies used in RM and REM sectors in comparison with foreign ones, currently provides parity in terms of processing of mineral raw materials. The implementation of the Roadmap for the Rare and Rare-Earth Metals product line will ensure at least $50 \%$ of import substitution of RM and REM by 2024 and achieve complete import substitution of RM and REM by 2030 , restore the leading position of the Russian Federation in the global market of RM and REM with a market share of at least $4 \%$ in 2024 and up to $10 \%$ in 2030.
\end{abstract}

Key words: rare metals, rare-earth metals, Energy transition, fuel and energy complex, strategy, sector, technologies. DOI: $10.17580 / \mathrm{nfm} .2021 .02 .01$

\section{Introduction}

$\mathrm{T}$ The Energy Transition currently determines the most accurate state of developed and developing economies, reflecting major energy policies and technologies transformations [1-3].

One of this paper's purposes is to analyze the correlations of energy transition with metals belonging to the group of rare and rare earths - as a resource necessary for this process.

Based on IEA experts [4], the growth of demand for REM will face the following difficulties [5] that increase risks for the global economy:

- the dominance of individual countries in value chains along their entire length from the extraction and processing of rare earth metals to the production of components (in China and the USA an internal technological chain has been established from mining to the production of final products; some countries are focused on the raw materials sector: Australia - on mining of rare earth metals, lithium, zirconium, Brazil and Canada - on mining of niobium, Chile - on mining of lithium) [6];

- negative environmental impacts from the use of certain production and technological operations;

- discrepancies in forecasts regarding the demand for individual REM, which can provoke abrupt price fluctua- tions for both the most (neodymium) and least (cerium) in-demand REM.

The indicator of world production of rare and rare earth metals for 2020 reached 815,000 tons [7].

At the same time, the world production of rare earth metals significantly lags behind the available reserves of raw materials (India, Russia, Brazil, and Vietnam).

According to the Rare and Rare Earth Metals Producers and Consumers Association Non-Profit Organization (NPO), the calculated volume of mining and production of rare metals in Russia in the perspective of 2030 is projected to be 43.000 tons per year, and the same indicator for rare earth metals is at least 30.000 tons per year [8] (Fig. 1). It is expected, however, that the consumption of rare and rare earth metals will decline relative to the production levels of the same year, when the supply of metals for lithium-ion and other modern batteries increased by 16.000 and 26.500 tons, respectively (Fig. 2).

As priority technologies of the Energy transition, where RM/REM can play a significant role, the following can be singled out:

- Solar photovoltaic technology;

- Offshore and onshore wind power technologies;

- Technologies for the production of hydrogen by electrolysis;

() Zhdaneev O. V., Petrov Ye. I., Seregina A. A., 2021 
- Energy storage and storage technologies;

- Technologies for the production of electric vehicles.

\section{Consumption and production of RM/REM in Russia until 2030}

According to the data from a survey of companies (letter from the Ministry of Energy of Russia No. ПС$6310 / 01$ dated June $1^{\text {st }}, 2021$ ), a total of up to 2.700 tons of RM are consumed in Russian fuel and energy complex

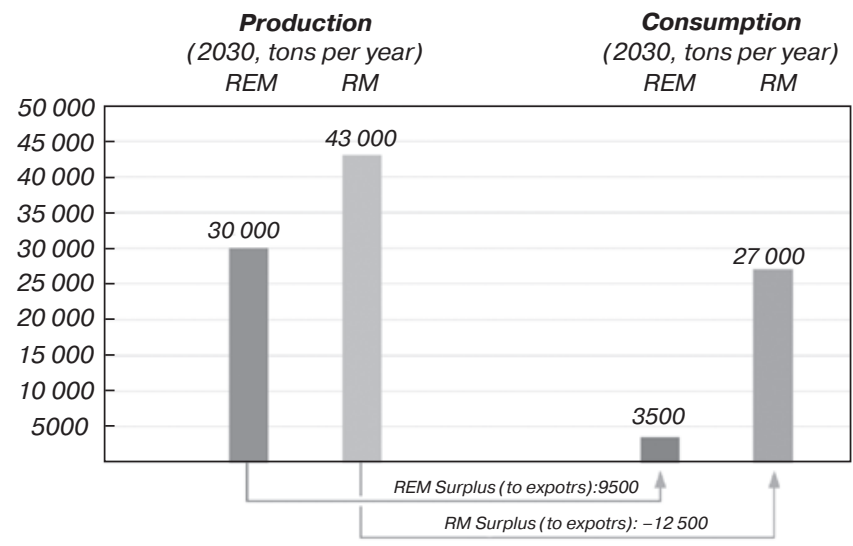

Fig. 1. Forecast of RM and REM production and consumption in Russia until 2030

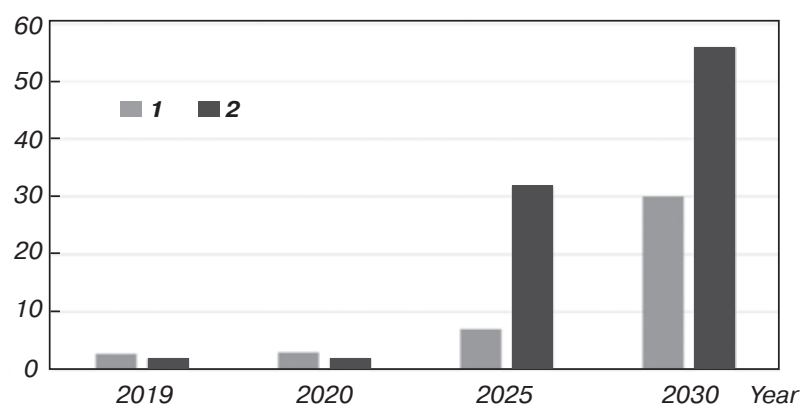

Fig. 2. Production of RM and REM in the Russian Federation, taking into account the implementation of the Roadmap for RM and REM (thousand tons): $1-\mathrm{REM} ; 2-\mathrm{KM}$
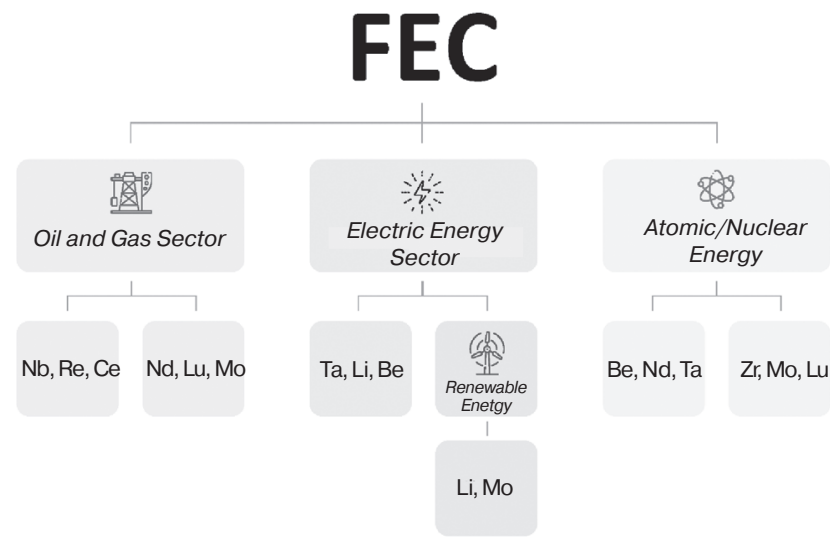

Fig. 3. The structure of RM and REM consumption in Russian fuel and energy complex annually: 1.100 tons are in the oil and gas sector and 1.600 are in the electric power sector. Niobium is most actively consumed: up to 2.300 tons, of which about 900 belongs to the oil and gas industry (Fig. 3).

In comparison to the total REM consumption rates in Russia, the oil and gas and electric power sectors of the FEC account for about 40\%: 500 out of 1,200 tons annually, including lanthanum, praseodymium, samarium, gadolinium and cerium. Furthermore, a survey conducted among Russian companies gives rise to a claim that there is an additional demand for REM in the amount of 105 tons annually ( 60 for lanthanum, 45 for neodymium).

At the same time, there is a clear diversification of consumption inside: about $65 \%$ of the consumed RM in the fuel and energy sector refers to industrial processes in the electric power sector, and 35\% -in the oil and gas sector. The consumption structure is also diversified: tantalum, lithium, beryllium and germanium (185 out of 1,600 tons) are used only in the electric power industries, while the consumption of RM in the oil and gas industries is reduced exclusively to neodymium ( 870 out of 870.9 tons annually).

The production of additional RM and REM in Russia can be met through the rising share of companies with sufficient experience in the field of metal mining. This is due to the high specific capital intensity of the mining sector and a long value-added chain when including the extracted element.

\section{Consumption of separated REM}

The consumption of REM in the form of final products in Russia is estimated at 1000 tons, providing by imports mainly (90\%).

The structure of REM consumption in Russia is as follows: producers of catalysts for cracking oil $-60 \%$, metallurgy $-15 \%$, glass industry $-10 \%$, renewable energy sources (permanent rare-earth magnets) $-2 \%$, nuclear power - $1 \%$ (Fig. 4).

Efforts to reduce dependence on REM and some RM imports are currently being carried out as part of the Technologies of new materials and substances Roadmap activities for the high-tech field developpment, approved by the Russian Government.

The Magnets project (implemented by TVEL JSC) is aimed at creating high-tech products - magnets for RES (renewable energy sources) [9] Commissioning and reaching the design capacity is envisaged by the project in 2025 with the annual production of permanent neodymium-iron-boron magnets in the amount of 1000 tons (in the interests of the wind power industry of the Russian Federation and enterprises producing special-purpose products).

The above projects are the most developed ones and will allow us to enter large-scale production of RM in 20252027 with the prospect of restoring Russia's position in the world market, resulting into a possible formation of a significant surplus. In this regard, the Department of Metallurgy and Materials of the Russian Ministry of Industry and Trade has already started working with trade missions of the 


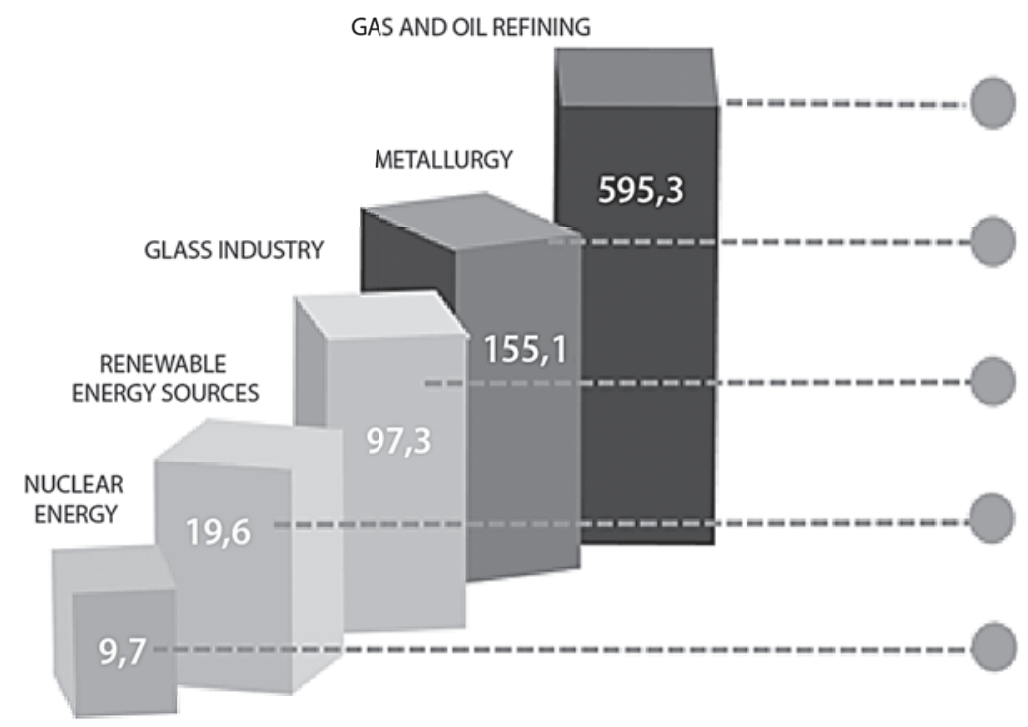

USE: $\mathrm{La}, \mathrm{Ce}, \mathrm{Nd}, \mathrm{Pr}$

- catalysts; 9 enterprises

USE: La, Ce, Nd, Er, Dv, La, Sc, Y

- alloys for transport engineering

- alloys for use in the oil and gas industry

$\mathbf{2 5}$ enterprises

USE: $\mathrm{La}, \mathrm{Ce}, \mathrm{Nd}$

- as an additive in the manufacture of glass;

- polishing of optical glasses

10 enterprises

USE: $N d, D y, P r, S m, G d, T b$

- permanent magnets;

5 enterprises

\section{USE: Gd, Er}

- burnable additives in uranium oxide fuel of WER

(PWF; pressured water reactor) and RBMK

(high-power channel-type reactor) reactors;

Rosatom State Corporation
Fig. 4. REM Consumption in the Russian Civil Sector (2020)

Russian Federation to find and establish business contacts with large foreign consumers of RM and REM to realize export potential.

Currently, a pilot industrial production with a capacity of up to 150 tons per year of REM has been created, the production technology has been matured, and the quality of products has been confirmed by potential buyers. It was planned that the Phosphogypsum project would completely cover the existing deficit in REM (1000 tons) by 2023. Planned points of reaching the design capacity $(2022-$ 500 tons per year of REM, 2023 - 1000 tons per year of REM, 2024-2025 - 4000 tons per year of REM). Along the way, within the framework of this project, the issue of improving the environmental situation is being solved the utilization of accumulated phosphogypsum dumps with the release of gypsum materials in demand in the construction industry. At the same time, the implementation of the project indicates the problem of low liquidity of light lanthanides, which is typical for all REM projects.

The implementation of the Tomtor deposit development project will allow to increase the raw material base and create capacities for the production of collective REM concentrate with subsequent access to export markets [10]. The project involves the production of 6 thousand tons of REM by 2027.

\section{Rare metals}

Dependence on imports is also typical for most rare metals.

The greatest deficit can be traced to niobium (3757 tons), tantalum (15 tons), zirconium (9659 tons), germanium (5 tons), lithium (1000 tons).

\section{RM consumption structure}

The main consumers are enterprises of the metallurgical complex, which receive more than 9 thousand tons (51\%)

\section{CIVIL sector TOTAL: 877 tons of REM}

of rare metals. The share of consumption by the glass industry equals to $8 \%$, about $5 \%$ falls on the radio-electronic industry, $11 \%-$ on the chemical industry (Fig. 5).

\section{The strategy of providing the necessary volume of RM / REM in the Russian Federation}

The production development of RM and REM is of critical importance to meet the needs of high-tech industries of the Russian Federation [11]. However, the current consumer demand for REM is almost $90 \%$ covered by imports (in processed form or as part of finished products). In addition, one of the main problems remains the insufficiency of the domestic market for the creation of competitive RM and REM branches of production.

To provide the domestic industries with the necessary volume of RM and REM, a Technologies of new materials and substances Roadmap for the development of the high-tech field in the Rare and Rare-Earth Metals product direction (hereinafter - the Roadmap) was developed. The Roadmap was developed in accordance with the Agreement of Intent between the Government of the Russian Federation and ROSATOM State Atomic Energy Corporation dated 10.07.2019 for the development of technologies of new materials and substances in the Russian Federation and approved by the decision of the Deputy Chairman of the Government of the Russian Federation Yu. I. Borisov dated 27.04.2020.

The projects within the framework of the Roadmap will ensure the creation of a full technological cycle industry in the Russian Federation with a wide range of products (26 metals in total), a complete technological chain from the extraction of raw materials to the final product, mainly high-tech products, the development of a diversified raw material base to ensure processing industries, as well as the creation of import-substituting industries for the main products of RM and REM. 


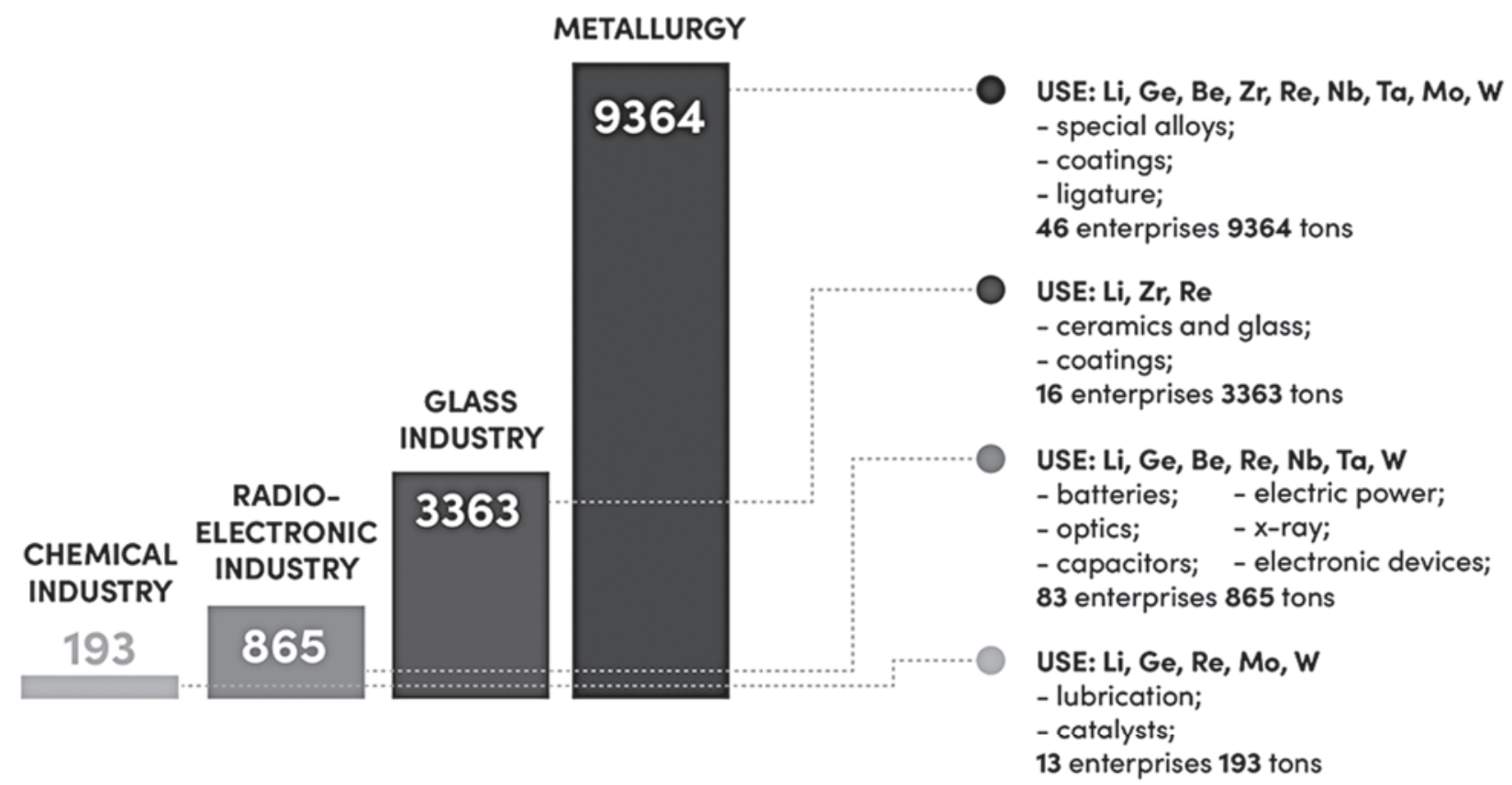

CIVIL SECTOR TOTAL: 13,785 tons of PM

Fig. 5. RM Consumption in the Russian Civil Sector (2020)

Two key advantages of the Russian Federation in this direction are rich unique deposits and facilities created in the USSR with highly specialized research institutes, which, with state support, can be reactivated and create a powerful, vertically integrated industry with state participation.

For that, it is currently necessary to implement the following measures aimed at maintaining and strengthening existing capacities and creating new ones. Possible measures of state support developed in the short term in conjunction with the Rare and Rare Earth Metals Producers and Consumers Association NPO, interested federal executive bodies and industry enterprises:

1. Creating conditions for providing the opportunity to receive subsidies to compensate for the interest rate on investment loans to new large-scale RM and REM projects put into operation until 2030 (the measure has been implemented).

2. Cancellation of the rental coefficient equal to 3.5 to the current MET rate for RM and REM, introduced by Federal Law No. 342-Ф3 of 15.10.2020 in order to eliminate administrative barriers to the use of the rental coefficient 1 (employment agreements, IPPA) for rare metal ores, the transfer of tungsten, molybdenum, titanium, zirconium under the effect of a reduction coefficient 0.1 , the introduction of a zero MET rate for tungsten and molybdenum for 5 years and the use of a rental coefficient 1.

3. Exclusion of the rental coefficient influence on the increase in the starting amount of a one-time payment for the use of mineral resources for deposits of rare metals, the use of a reduction coefficient 0.1 characterizing the features of the extraction of rare metals.

4. Elimination of restrictions in the application of a system-wide support measure within the framework of the SPIC for rare metal industry projects. The new mechanism for granting preferences within the framework of the SPIC limits the use of this mechanism to companies investing in projects for the extraction and processing of mining products based on the introduction of modern technologies, but do not aim to produce mining equipment. The reservation does not allow for practical implementation of projects within SPIC, such as Titanium, Germanium even with the introduction of modern technologies in the list of types of technologies in order to enter into a SPIC, approved by order of the Russian Government of 28.11.2020 No. 3143-p.

5 . The possibility to recalculate unclaimed (but contained as coproducts in ore) mineral reserves, which have a significant impact on the cost of the initial one-time payment for the use of mineral resources, on the government balance sheet, as it limits cost-efficiency of the projects aimed at extracting the main mineral (for example, titanium, zirconium, lithium).

State support measures developed in the long term in conjunction with the Rare and Rare Earth Metals Producers and Consumers Association NPO, interested federal executive bodies and industry enterprises:

1. Consideration of the possibility to provide subsidies for the shortfall in income of domestic producers of RM and REM in the event of price reduction on the foreign market below the cost of production (during the first 5 years from the start of production). 
2. Creation of a mechanism for companies to obtain long-term loans with state guarantees for the implementation of strategically important projects.

3. Receiving state investment in order to create the supporting infrastructure necessary for the implementation of rare metal projects.

In the production direction - production of concentrates and separation into oxides:

1. Introduction of technologies ( $R \& D$ results) obtained with the support of the Ministry of Industry and Trade of Russia as part of the implementation of the $1^{\text {st }}$ stage of the Development of traditional and new materials production subprogram of the Development of Industry and increasing its competitiveness state program.

2. Development of technologies for processing and recycling of raw materials, waste recycling.

Another necessary aspect is the use of fiscal stimulus measures from the Industrial Development Fund and Russia's national economic development institution "VEB.RF".

In general, the development of the RM and REM industry is to be divided into stages: first, formation a raw material reserve - the implementation of projects for the extraction of RM and REM; then, the development of processing industries, which will allow the production of individual metals (including separated REM) on an industrial scale; later, gradual development of production related to the consumption and use of RM and REM for the final product, mainly high-tech products.

Such a step-by-step approach will allow restoring a full-cycle industry independent of external supplies and integrating into global technological chains of production of high-value-added products, including with localization of production in the Russian Federation [12].

\section{Problems and challenges}

The main problems and challenges that need to be addressed are listed in the Table $\mathbf{1 .}$

\section{Solution proposals: specific with projected effects and required resources}

More detailed information and proposals are set out in full in the Roadmap approved by the Russian Government for the development of the "Technologies of new materials and substances" high-tech field in the "Rare and rare earth metals" product direction.

\section{Vision of the future}

With the participation of the Rare and Rare Earth Metals Producers and Consumers Association NPO, the following strategic goals for the development of the product line of RM and REM have been developed:

Goal 1. To meet the needs of Russian industry in RM, including those produced abroad under the control of Russian organizations, by 50\% in 2024, by $100 \%$ in 2030 .

Goal 2. To meet the needs of Russian industry in Russian REM by $80 \%$ in 2024 , by $100 \%$ in 2030 .

Goal 3. To enter the TOP 5 global REM producers with a global market share of at least $5 \%$ in 2024, at least $10-12 \%$ in 2030.

Goal 4. To enter the TOP 5 world RM producers with a global market share of at least 4\% in 2024, at least 9\% in 2030.

Table 1

Problems, challenges and possible solutions

\begin{tabular}{|c|c|}
\hline Problems and challenges & Possible solutions \\
\hline $\begin{array}{l}\text { Risks of supply monopoly, the possibility of dumping for the } \\
\text { market collapse (similar to the REM crisis of the 2010s), } \\
\text { price volatility }\end{array}$ & $\begin{array}{l}\text { - Integration with high-conversion manufacturers } \\
\text { - State support, including for the formation of a diversified portfolio of } \\
\text { projects taking into account economic efficiency and country risks } \\
\text { - Production of margin metals and materials }\end{array}$ \\
\hline $\begin{array}{l}\text { Imbalance of supply and demand in Russia, low share in the } \\
\text { global market }\end{array}$ & $\begin{array}{l}\text { - Signing of offtake contracts } \\
\text { - Integration into global production chains } \\
\text { - Support of export-oriented industries }\end{array}$ \\
\hline Low-tonnage and finely-dispersed demand & $\begin{array}{l}\text { - Stimulating the development of consumer industries in the Russian } \\
\text { Federation } \\
\text { - Localization of consumer industries in the Russian Federation } \\
\text { - Creation of experimental-industrial production facilities at anchor } \\
\text { plants }\end{array}$ \\
\hline $\begin{array}{l}\text { Weak profitability of the domestic mineral resource base } \\
\text { (lithium and a number of other metals) }\end{array}$ & $\begin{array}{l}\text { - Acquisition of high-quality mineral resources abroad } \\
\text { - Development of technologies for the cost-effective explorationof } \\
\text { a low-quality mineral resource base }\end{array}$ \\
\hline Disparate actors, broken technological chains & $\begin{array}{l}\text { - Restoration of full technological cycle production } \\
\text { - State support: } \\
\text { - development of the industrial clusters practice, including the cre- } \\
\text { ation and development of PSEDA } \\
\text { - subsidizing the creation of industrial infrastructure projects in the } \\
\text { Russian Federation }\end{array}$ \\
\hline $\begin{array}{l}\text { The negative impact of traditional production technologies } \\
\text { on the preservation of the environment }\end{array}$ & $\begin{array}{l}\text { - Development and implementation of environmentally friendly tech- } \\
\text { nologies (with minimal impact on biocenosis, water balance, envi- } \\
\text { ronment and regional climate) } \\
\text { - Creation of a REM processing center in Krasnokamensk }\end{array}$ \\
\hline
\end{tabular}


The targets of the roadmap and its target values for 2024:

1. Share of the REM global market $-5 \%$.

2. Share of the RM global market $-4 \%$.

3. The volume of REM production -7 thousand tons.

4. The volume of RM production -11.8 thousand tons.

5. Divided REM output $-55 \%$ of the total (from the total release of REM).

6. Annual revenue -56.9 billion rubles.

7. The state of RM and REM industry development the launch of mining and processing industries, the reduction of import dependence, the growth of domestic RM and REM consumption.

8. The number of active RM and REM sources 9 units.

9. Dependence on REM imports $-20 \%$.

10. Dependence on RM imports - at least $50 \%$.

\section{Conclusions}

The implementation of the Roadmap for the Rare and Rare-earth metals product line will ensure at least $50 \%$ import substitution of RM and REM by 2024 and achieve full import substitution of RM and REM by 2030, restore the leading positions of the Russian Federation in the world market of RM and REM with a market share of at least $4 \%$ in 2024 and up to $10 \%$ in 2030.

Thus, to date, the main groundwork has been created for the revival of the domestic industry of rare and rare earth metals as follows:

1. The Roadmap for the development of the Rare and Rare Earth Metals product line was created and approved by the Government of the Russian Federation. The roadmap is periodically updated, work is underway to consider new promising projects of RM and REM.

2. A portfolio of top-priority projects has been formed, ensuring the achievement of the strategic development goals of the RM and REM industry for the period up to 2024 and 2030. The main task of these projects is the creation and gradual increase of separation capacities, which will cover the internal needs of domestic producers in separated REM oxides, the list of rare metals, as well as entering the international market with products of higher value added.

3. In order to implement interrelated projects in the interests of developing the Roadmap for the Rare and Rare Earth Metals product area, a tool for creating product chains was developed and implemented - framework agreements with the main participants in the RM and REM market.

4. The mineral resource base of the Russian Federation in relation to each of the rare and rare earth elements is significant and allows the country to occupy a leading position in reserves in the world, which is the basis for the development of mining and processing industries.

\section{Acknowledgements}

We express our gratitude to the Rare and Rare Earth Metals Producers and Consumers Association NPO represented by its Chairman R. R. Dimukhamedov for assistance in collecting analytical materials and writing a paper.

\section{References}

1. Dados N., Connell R. The Global South. Contexts. 2012. Vol. 11, Iss. 1. pp. 12-13.

2. Lattanzio R. K. Paris Agreement: U.S. Climate Finance Commitments. CRS Reports. Washington: Congressional Research Service, 2017. $9 \mathrm{p}$.

3.Zhdaneev O. V., Chuboksarov V. S. Technical Policy of the Oil and Gas Industry in Russia: Tasks and Priorities. Energy Policy. 2020. No. 5. pp. 76-91.

4. The Role of Critical Minerals in Clean Energy Transitions. World Energy Outlook Special Report. 2021. Available at: https://iea.blob.core.windows.net/assets/24d5dfbb-a77a-4647abcc-667867207f74/The Roleof Critical Mineralsin Clean Energy Transitions.pdf (accessed: 20.12.2021).

5. Temnov A. V., Azarnova L. A. The Role of Rare Metals in Providing Leading Foreign Countries with Strategic And Critical Mineral Resources. Mineralnye Resursy Rossii. Ekonomika $i$ Upravlenie. 2016. No.1-2. pp. 100-106.

6.van Exter P., Bosch S., Schipper B., Sprecher B., Kleijn R. Metal Demand For Renewable Electricity Generation In The Netherlands. Navigating a Complex Supply Chain. Available at: https://www.metabolic.nl/publications/metal-demand-for-renewable-electricity-generation-in-the-netherlands-pdf/ (accessed: 20.12.2021).

7. Garside M. Rare Earth Reserves Worldwide as of 2020, by Country. Statista. Available at: https://www.statista.com/ statistics/ 277268/rare-earth-reserves-by-country/ (accessed: 20.12.2021).

8. Dyatel T., Zaynullin E. With Unprecedented Rhenium. How Russia Plans to Become a Leader in the Production of Rare Metals. Kommersant. 04 December 2020. Available at: https:// www.kommersant.ru/doc/4596106 (accessed: 20.12.2021).

9. Tchizhevsky A. TVEL Localizes the Production of Magnets from Rare Earth Alloys for Wind Power Generators. Neftegaz.ru. 05 November 2020. Available at: https://neftegaz.ru/ news/Alternative-energy/638197-tvel-lokalizuet-proizvodstvomagnitov-iz-redkozemelnykh-splavov-dlya-generatorov-vetryanykh-elektros/ (accessed: 20.12.2021).

10. Tomtor Deposite. Available at: https://arctic-russia.ru/ project/tomtorskoe-mestorozhdenie/ (accessed: 20.12.2021)

11. Bykhovsky L. Z., Tigunov L. P., Temnov A. V. On the Definition of the Notion of Rare Elements (Rare Metals): Historical and Terminological Aspects. Mineralnye Resursy Rossii. Ekonomika i Upravlenie. 2015. No. 3. pp. 32-38.

12. Samsonov N. Yu. Global Chains of Supply of RareEarth and Rare Metals as High-Tech Raw Materials Within the Framework of International Industrial Cooperation. Spatial Economics. 2018. Vol. 3. pp. 43-66. 